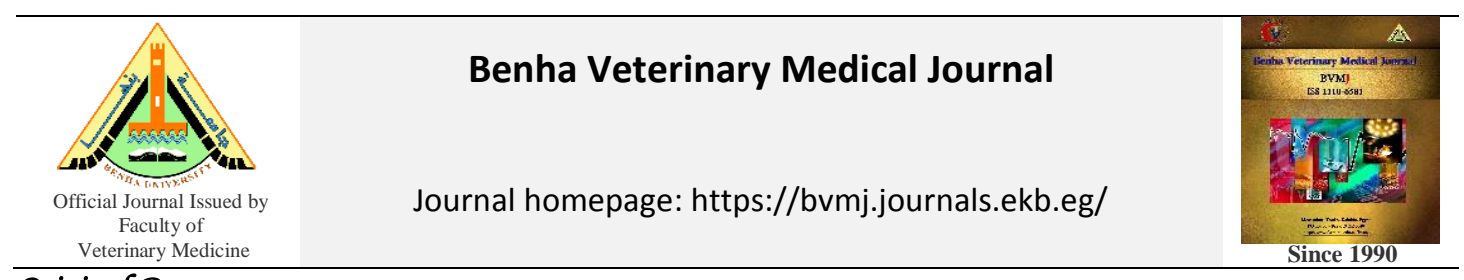

Original Paper

\title{
Determination of histamine level in frozen fish in relation to bacterial contamination
} Mohammed A. Hassan and Safa M. Hussam

Food Hygiene and control Department, Faculty of Veterinary Medicine, Benha University

\begin{tabular}{|c|c|}
\hline ARTICLE INFO & ABSTRACT \\
\hline $\begin{array}{l}\text { Keywords } \\
\text { Coliform, } \\
\text { Enterobacteriaceae } \\
\text { Histamine, } \\
\text { Oreochromis niloticus } \\
\text { S. aureus } \\
\text { Scomber scombrus } \\
\text { Received } 06 / 12 / 2020 \\
\text { Accepted } 23 / 12 / 2020 \\
\text { Available On-Line } \\
\text { 20/01/2021 }\end{array}$ & $\begin{array}{l}\text { Histamine is a member of compounds called biogenic amines produced by decarboxylation } \\
\text { of free amino acids and present in a many types of foods. Production of amine in concert of } \\
\text { the Biogenic Amines (BA) in fish represents a health risk to human food intoxication. In this } \\
\text { study ninety random frozen fish samples pictured by Scomber scombrus, Saurus and } \\
\text { Oreochromis niloticus ( } 30 \text { of each) were collected from markets in Kalyobia Governorate to } \\
\text { work out the microorganism count of Coliform, Staphylococcus aureus and } \\
\text { Enterobacteriaceae and examined for the presence of amine by assay. The results of } \\
\text { examination for frozen fish discovered that Enterobacteriaceae counts were recorded as } 29 \\
\text { positive samples with percentage of }(96.7 \%) \text { from frozen Scomber scombrus samples, } 26 \\
\text { positive samples with percentage of }(86.7 \%) \text { from frozen Saurus samples and } 24 \text { positive } \\
\text { samples with percentage of ( } 80 \%) \text { from frozen Oreochromis niloticus additionally, Coliform } \\
\text { counts were } 27 \text { positive samples with percentage of ( } 90 \%) \text { from frozen Scomber scombrus } \\
\text { samples, } 25 \text { positive samples with percentage of ( } 83.3 \% \text { ) from frozen Saurus samples and } 23 \\
\text { positive samples with percentage of ( } 76.7) \text { from frozen Oreochromis niloticus. Also, the study } \\
\text { discovered that } S \text {. aureus counts were } 22 \text { positive samples with percentage of ( } 73.3 \% \text { ) from } \\
\text { examined Scomber scombrus }, 17 \text { positive samples with percentage of (56.7\%) from Saurus } \\
\text { and } 14 \text { positive samples with percentage of ( } 46.7 \% \text { ) from Oreochromis niloticus . Mistreatment } \\
\text { assay check, the results recorded that the amine mean values in examined fish samples were } \\
\text { twenty-nine. } 40 \pm 0.31,21.76 \pm 0.25 \text { and } 16.23 \pm 0.18 \text { mg/kg for Scomber scombrus, Saurus and } \\
\text { Oreochromis niloticus severally. Once and for all, the appliance of early detection of biogenic } \\
\text { amines primarily amine manufacturing microorganism may scale back the health risk of amine } \\
\text { intoxication associated fish and fish product microbial deterioration. Improvement of a } \\
\text { selective medium to observe decarboxylating microorganism could also be a valuable tool. }\end{array}$ \\
\hline
\end{tabular}

\section{INTRODUCTION}

Fish quality is a complex concept involving many factors that embody for example: safety, nutritional quality, handiness, convenience and integrity, freshness, intake quality and therefore the obvious physical attributes of the species, size and product type (Abbas et al., 2008). The quality of fish and fishery products represent a significant concern in fish industry everywhere the globe (Huss et al., 2003).

Temperature and handling practices are necessary factors in determining the shelf life of all species of fish, if the fish product is handled rigorously, the temperature at which is held, control its useful life. Temperature can manage the rate of microorganism spoilage and enzyme breakdown, the higher the temperature the quicker the fish spoils (BaggeRavn et al., 2003)

Freezing preserves the taste, texture and nutritional value of foods better than the other strategies (George, 1997). Freezing of fish cause many chemical changes as increasing in $\mathrm{pH}$, total volatile base nitrogen, Thiobarbituric acid number, acid number, acid value and free fatty acids as a results of lipid oxidization in fish, whereas organoleptic attributes as odor, taste and texture were decreased throughout frozen storage period (Simeonidou et al., 1997). Freshness assurance is one of the most necessary goals for the fish industry as freshness is closely associated with quality. Sensory, chemical/biochemical and microbiological strategies conventionally wont to measure the degree of fish freshness. Texture and color analysis moreover as determination of post-mortem $\mathrm{pH}$ offer indications of physical changes occurring in fish muscle throughout storage (Izumi, 2012).

The Biogenic Amines (BA) are produced during the end of shelf life and thus their levels will be considered as a spoilage index instead of a high-quality index (Ozogul and Ozogul, 2006). Although several are found in fish, the most common BA found in foods and causing histamine poisoning and toxicity caused by histamine, cadaverine, tyramine, agmatine, spermine, tryptamine, 2phenylethylamine, spermidine and ptomain (Ladero et al., 2010; Naila et al., 2010; Chong et al., 2011; Naila, et al., (2012).

Various species of family Enterobacteriaceae contain histidine decarboxylase and have the ability to produce histamine (Huang et al., 2010).

Biogenic amines like ptomain, putrescine, spermidine and spermine don't have any adverse health effect, but sometimes they react with nitrite to form carcinogenic nitrosamines (Onal et al., 2013).

Fresh fish don't contain free histamine however contain amino acid L-histidine. Histamine is made in fish by certain microorganism capable of producing histidine decarboxylase enzyme which can converse the free

* Corresponding author: sfhsm@yahoo.com 
histidine, naturally present within the muscle of some fish, to histamine (FAO/WHO, 2013).

High amounts of BA are produced considerably throughout processing and storage of food as a results of microbial contamination and inadequate storage conditions through decarboxylation of specific free amino acids by exogenous decarboxylase enzymes released by microorganisms related to seafood. Biogenic amines like histamine, ptomain and ptomain are considered as indicators of fish spoilage (Lee et al., 2015; Biji et al., 2016).

Therefore, the goal of this study is to judge the effect of microorganism producing histamine on quality of frozen fish

\section{MATERIAL AND METHODS}

A total of ninety random frozen fish samples represented by Scomber scombrus, Saurus and Oreochromis niloticus $(30$ of each) were collected from completely different fish markets settled in Kalyobia Governorate. Every sample was kept in a separate sterile bag and preserved in an ice box then transferred to the laboratory below complete sterile conditions while not undue delay and examined as quickly as doable. The collected samples were subjected to bacteriological examination to see the connection between the presence of bound microorganism and therefore the quality of such examined frozen fish.

\subsection{Bacteriological examination:}

2.1.1. Preparation of samples (ISO 4833-1, 2013): Twentyfive grams of the sample, $225 \mathrm{ml}$ of sterile organic compound water were side and totally mixed mistreatment sterile liquidizer for one. 5 minutes, from that 10 -fold serial dilutions was ready. The ready samples were subjected to the subsequent examinations.

2.1.2. Enterobacteriaceae Count (ISO 4833-1, 2013)

One $\mathrm{ml}$ from every of the antecedently ready dilution was transferred into 2 separate sterile Petri-dishes to that around fifteen $\mathrm{ml}$ of sterile thawed and tempered Violet Red digestive fluid aldo hexose agar $\left(45^{\circ} \mathrm{C}\right)$ were side. once thorough commixture, the inoculated plates were allowed to solidify before being incubated at $37^{\circ} \mathrm{C}$ for twenty-four hours All purple colonies were then counted and therefore the family Enterobacteriaceae count per gram was calculated on plates containing 30-300 colonies and every count was recorded severally.

2.1.3. Total coliform count:

Violet Red digestive fluid agar medium, constant technique of the previous pour plate methodology was applied mistreatment Violet Red digestive fluid agar medium. The plates were incubated at $37^{\circ} \mathrm{C}$ for twenty-four hours. All red colonies measurement zero. 5 metric linear unit in diameter on the plates were then counted and therefore the average range of colonies decided.

2.1.4. Determination of Staph. aureus count (FDA, 2001): One $\mathrm{ml}$ from every of antecedently ready serial dilutions was cover Baired Parker agar plate employing a sterile bent glass spreader. The plates were preserved in upright position till the matter is absorbed by agar for regarding ten min, or placed in up right within the brooder for regarding one hour. The inoculated and management plates were inverted and incubated at $37^{\circ} \mathrm{C}$ for forty-eight hours. once that they were examined for colony character. The developed colonies (shiny black colonies) were enumerated as presumptive Staph. aureus count/g was calculated. Also, the colonies were picked up and sublimate on culture medium slopes for more identification.

2.2. Determination of histamine by ELISA (Leszczynskai et al., 2004):

- Intended use and principle of the test:

This enzyme immunoassay is for the quantitative determination of histamine in plasma and urine as well as different tissues of the body. In combination with supplementary kit (available for purchase separately, cat. no. BA E-1100), the assay is performed for the determination of histamine release in heparinized whole blood and tissues of the body. First, histamine is quantitively acylated. The subsequent competitive ELISA kit uses the microtiter plate format. The antigen is bound to the solid phase of the microtiter plate. The acylated standards controls, samples, and the solid phase bound analyte compete for a fixed number of antiserum binding sites. After the system is in equilibrium, free antigen and free antigen-antiserum complexes are removed by washing. The antibody bound to the solid phase is detected by an anti-rabbit IgG- peroxidase conjugate using TMB as a substrate. The reaction is monitored at $450 \mathrm{~nm}$. Quantification of unknown samples is achieved by comparing their absorbance with a reference curve prepared with known standard concentrations.

\section{- Test procedure:}

All reagents and samples are allowed to reach room temperature prior to use. Measurement in duplicates is recommended.

\subsubsection{Preparation of reagents:}

- Wash Buffer

Dilute the $20 \mathrm{ml}$ wash buffer concentrate with distilled water to a final volume of $1,000 \mathrm{ml}$. Storage up to 6 months at $4-$ $8^{\circ} \mathrm{C}$.

- Acylation Diluent

The Acylation Diluent has a freezing point of $18.5^{\circ} \mathrm{C}$. To ensure that the Acylation Diluent is liquid when being used, it must be ensured that the Acylation Diluent has reached room temperature and forms a homogeneous, crystal-free solution before being used. Alternative the Acylation Diluent can be stored at room temperature $\left(20-25^{\circ} \mathrm{C}\right)$ separate from the other kit components.

- Acylation Reagent Reconstitute each vial with $1.25 \mathrm{~mL}$ Acylation Diluent. The Acylation Reagent has to be newly prepared prior to the assay (not longer than 1 hour in advance). If more than 1.25 $\mathrm{mL}$ is needed, pool the contents of 2 or 3 vials and mix thoroughly.

\subsubsection{Sample preparation and acylation:}

- Pipette $25 \mu \mathrm{l}$ of standards, $25 \mu \mathrm{l}$ of controls, $25 \mu \mathrm{l}$ of plasma samples, $10 \mu 1$ of urine samples, or $50 \mu 1$ of supernatant from the release test* into the respective wells of the reaction plate.

- Add $25 \mu 1$ of acylation buffer to all wells.

- Add $25 \mu$ l of acylation reagent to all wells.

- Incubate for $45 \mathrm{~min}$ at $\mathrm{rt}\left(20-25^{\circ} \mathrm{c}\right)$ on a shaker (approx. 600 rpm).

- Add $200 \mu 1$ of distilled water to all wells.

- Incubate for $15 \mathrm{~min}$. At rt $\left(20-25^{\circ} \mathrm{c}\right)$ on a shaker (approx. 600 rpm).

- Take $25 \mu \mathrm{l}$ of the prepared standards, controls, and samples for the Histamine ELISA.

* For the release test the Histamine Release supplementary kit (available for purchase separately, cat. no. BA E-1100) has to be used. 


\subsubsection{Histamine ELISA}

- Pipette $25 \mu$ l of the acylated standards, controls, and samples into the appropriate wells of the histamine microtiter strips.

- Pipette $100 \mu \mathrm{l}$ of the histamine antiserum into all wells and cover plate with adhesive foil.

- Incubate for 3 hours at $\mathrm{rt}\left(20-25^{\circ} \mathrm{c}\right)$ on a shaker (approx. 600 rpm).

- Alternatively, shake the histamine microtiter strips briefly by hand and incubate for $15-20$ hours at $2-8^{\circ} \mathrm{C}$.

- Remove the foil. Discard or aspirate the contents of the wells and wash each well 4 times thoroughly with $300 \mu 1$ wash buffer. Blot dry by tapping the inverted plate on absorbent material.

- Incubate for $30 \mathrm{~min}$ at $\mathrm{rt}\left(20-25^{\circ} \mathrm{C}\right)$ on a shaker (approx. 600 rpm).

- Discard or aspirate the contents of the wells and wash each well 4 times thoroughly with $300 \mu 1$ wash buffer. Blot dry by tapping the inverted plate on absorbent material.

- Pipette $100 \mu \mathrm{l}$ of the substrate into all wells and incubate for $20-30 \mathrm{~min}$ at $\mathrm{rt}\left(20-25^{\circ} \mathrm{C}\right)$ on a shaker $(600 \mathrm{rpm})$. Avoid exposure to direct sunlight.

- Add $100 \mu 1$ of the stop solution to each well and shake the microtiter plate to ensure a homogeneous distribution of the solution.

- Read the absorbance of the solution in the wells within 10 minutes, using a microplate reader set to $450 \mathrm{~nm}$ with a reference wavelength between $620 \mathrm{~nm}$ and $650 \mathrm{~nm}$.

\subsubsection{Calculation of results:}

\begin{tabular}{lllllll}
\hline \multicolumn{7}{c}{ Concentration of the standards } \\
\hline Standard & A & B & C & D & E & F \\
Histamine $(\mathrm{ng} / \mathrm{mL}=\mu \mathrm{g} / \mathrm{L})$ & 0 & 0.5 & 1.5 & 5 & 15 & 50 \\
Histamine $(\mathrm{nmol} / \mathrm{L})$ & 0 & 4.5 & 13.5 & 45 & 135 & 450 \\
Conversion: & \multicolumn{5}{l}{ Histamine $(\mathrm{ng} / \mathrm{mL})$} & $9=$ Histamine $(\mathrm{nmol} / \mathrm{L})$
\end{tabular}

- The calibration curve is obtained by plotting the absorbance readings (calculate the mean absorbance) of the standards (linear, y-axis) against the corresponding standard concentrations (logarithmic, $\mathrm{x}$ - axis). Use a non-linear regression for curve fitting (e.g., spline, 4- parameter, akima). The concentrations of the plasma samples and the controls can be read directly from the standard curve.

\subsubsection{Quality control:}

It is recommended to use control samples according to state and federal regulations. Use controls at both normal and pathological levels. The kit controls, or other commercially available controls, should fall within established confidence limits. The confidence limits of the kit controls are printed on the QC- Report.

\subsubsection{Calibration:}

The binding of the antisera and the enzyme conjugates and the activity of the enzyme used are temperature dependent, and the extinction values may vary if a thermostat is not used. The higher the temperature, the higher the extinction values will be. The extinction values also depend on the incubation times. The optimal temperature during the Enzyme Immunoassay is between $20-25^{\circ} \mathrm{C}$. In cases of overflow, read the absorbance of the solution in the wells within 10 minutes, using a microplate reader set to $405 \mathrm{~nm}$.

\subsection{Statistical Analysis:}

The obtained results were statistically evaluated by application of Analysis of Variance (ANOVA) test as well as correlation coefficient between the histamine limits Vs bacteriological profile of the examined frozen fish samples (Feldman et al., 2003). All data were presented as mean \pm Standard error of mean (SEM). Differences in mean of analyzed data were considered significant at $\mathrm{P} \leq 0.05$.

\section{RESULTS}

Table (1) revealed that Enterobacteriaceae was isolated from examined frozen fish samples represented as 29 (96.7\%) from Scomber scombrus , 26(86.7\%) from Sảurus and $24(80 \%)$ from Oreochromus niloticus . Meanwhile, the mean values of Enterobacteriaceae count $(\mathrm{cfu} / \mathrm{g}$ ) in the examined samples were $2.09 \times 10^{4} \pm 0.41 \times 10^{4}, 1.27 \times 10^{4} \pm$ $0.19 \times 10^{4}$ and $5.45 \times 10^{3} \pm 0.74 \times 10^{3}$ from Mackerel, Sảurus and Oreochromus niloticus respectively. Furthermore ;Table (2) revealed that coliform was isolated from examined frozen fish samples represented as $27(90 \%)$ from Scomber scombrus , 25 (83.3\%) from Sảurus and 23 (76.7\%) from Oreochromus niloticus respectively.

Tables (3) revealed that Staph. aureus was isolated from examined frozen fish samples represented as 22(73.3\%) from Scomber scombrus , 17(56.7\%) from Sảurus and 14(46.7\%) from Oreochromus niloticus . Meanwhile, the mean values of Staph. aureus count (cfu/g) in the examined samples were $4.35 \times 10^{3} \pm 0.62 \times 10^{3}, 1.81 \times 10^{3} \pm 0.29 \times 10^{3}$ and $9.1 \times 10^{2} \pm 2.06 \times 10^{2}$ from Mackerel, Sảurus and Oreochromus niloticus, respectively.

Table (4) indicated analysis of histamine levels $\mathrm{mg} \%$ in the examined samples of frozen fish with mean value of $29.40 \pm$ $0.31,21.76 \pm 0.25$ and $16.23 \pm 0.18$ for Scomber scombrus , Saurus, Oreochromus niloticus, respectively .

Table (5) indicate correlation coefficient ( $r$ ) between histamine levels Vs. bacteriological quality of the examined frozen fish samples.

Table 1 Statistical analysis of Enterobacteriaceae counts (cfu/g) in the examined samples of frozen fish $(\mathrm{n}=30)$.

\begin{tabular}{|c|c|c|c|c|c|}
\hline \multirow[b]{2}{*}{ Frozen fish species } & \multicolumn{5}{|c|}{ +ve samples } \\
\hline & No. & $\%$ & Min & $\operatorname{Max}$ & Mean \pm S.E $E^{*}$ \\
\hline Scomber scombrus & 29 & 96.7 & $1.9 \times 10^{3}$ & $6.2 \times 10^{4}$ & $\begin{array}{l}2.09 \times 10^{4} \pm \\
0.41 \times 10^{4}\end{array}$ \\
\hline Saurus & 26 & 86.7 & $1.1 \times 10^{3}$ & $3.5 \times 10^{4}$ & $\begin{array}{l}1.27 \times 10^{4} \pm \\
0.19 \times 10^{4}\end{array}$ \\
\hline $\begin{array}{l}\text { Oreochromis } \\
\text { niloticus }\end{array}$ & 24 & 80 & $7.0 \times 10^{2}$ & $8.9 \times 10^{3}$ & $\begin{array}{l}5.45 \times 10^{3} \pm \\
0.74 \times 10^{3}\end{array}$ \\
\hline
\end{tabular}

Table 2 Statistical analysis of Coliform counts $(\mathrm{cfu} / \mathrm{g})$ in the examined samples of frozen fish $(n=30)$.

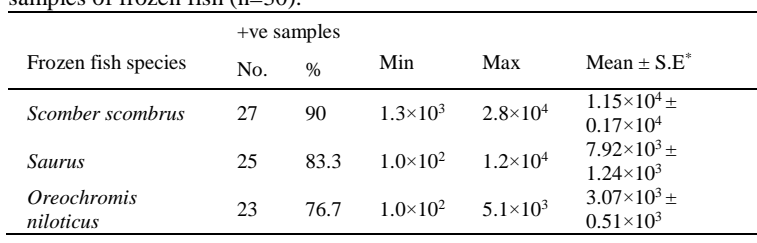

Table 3 Statistical analysis of Staph. aureus counts (cfu/g) in the examined samples of frozen fish $(n=30)$.

\begin{tabular}{|c|c|c|c|c|c|}
\hline \multirow[b]{2}{*}{ Frozen fish species } & \multicolumn{5}{|c|}{ +ve samples } \\
\hline & No. & $\%$ & Min & Max & Mean \pm S.E \\
\hline Scomber scombrus & 22 & 73.3 & $5.0 \times 10^{2}$ & $9.0 \times 10^{3}$ & $\begin{array}{l}4.35 \times 10^{3} \pm \\
0.62 \times 10^{3}\end{array}$ \\
\hline Saurus & 17 & 56.7 & $2.0 \times 10^{2}$ & $4.0 \times 10^{3}$ & $\begin{array}{l}1.81 \times 10^{3} \pm \\
0.29 \times 10^{3}\end{array}$ \\
\hline $\begin{array}{l}\text { Oreochromis } \\
\text { niloticus }\end{array}$ & 14 & 46.7 & $1.0 \times 10^{2}$ & $2.0 \times 10^{3}$ & $\begin{array}{l}9.10 \times 10^{2} \pm \\
2.06 \times 10^{2}\end{array}$ \\
\hline
\end{tabular}

Table 4 Statistical analysis of histamine levels "mg\%" in the examined $\underline{\text { samples of frozen fish }(\mathrm{n}=30)}$.

\begin{tabular}{llll}
\hline Frozen fish species & Min & Max & Mean \pm S.E \\
\hline Scomber scombrus & 4.65 & 51.78 & $29.40 \pm 0.31$ \\
Saurus & 4.02 & 38.93 & $21.76 \pm 0.25$ \\
Oreochromis niloticus & 3.51 & 27.47 & $16.23 \pm 0.18$ \\
\hline
\end{tabular}


Table 5 Correlation coefficient (r) between histamine levels Vs. bacteriological quality of the examined frozen fish samples.

\begin{tabular}{llll}
\hline Frozen fish species & Scomber scombrus & Saurus & O.niloticus \\
\hline Bacterial counts: & & & \\
Enterobacteriacae count & $+0.72^{* *}$ & $+0.66^{* *}$ & $+0.54^{*}$ \\
Coliform count & $+0.63^{* *}$ & $+0.58^{* *}$ & $+0.49^{*}$ \\
Staph aureus count & $+0.59^{* *}$ & $+0.50^{*}$ & $+0.47^{*}$ \\
\hline * Significant correlation. ** High significant correlation & &
\end{tabular}

\section{DISUCSSION}

Fish and their products are important source of protein, and other elements necessary for the healthy body maintenance. fish constitute an important food component for a large section of the world population, the fish quality is of major concern to the food processors, consumers, and public health authorities. Provision of safe, wholesome and acceptable fish and fish products, though control of contamination is essential from food safety point of view. the quality of fish degrades due to a complex process in which physical, chemical and microbiological forms of deterioration are implicated (Adebayo-Tayo et al., 2012) .

The detection of potential contaminants in harvested ocean food is terribly crucial to confirm safety of consumer. Further analysis on the microbial quality assessment of fish and fishery products ought to be undertaken. Cooking properly immediately before consumption is additionally an effective method of reducing or eliminating risk of fresh fish-borne diseases

The results in table (1) showed that the mean values of Enterobacteriaceae count/gm of Scomber scombrus, Saurus and Oreochromus niloticus are $2.09 \times 10^{4} \pm 0.41 \times 10^{4}, 1.27 \mathrm{x}$ $10^{4} \pm 0.19 \times 10^{4}$ and $5.45 \times 10^{3} \pm 0.74 \times 10^{3}$ respectively. The number of positive samples of Mackerel are 29 with percent of 96.7 , Saurus are 26 with percent of 86.7 and Oreochromus niloticus are 24 with a percent of 80 . Food concerned as a vehicle in food borne illness, sometimes contain bacteria of uncertain significance to human health, among these organisms Citrobacter, Klebsiella, Proteus and Enterobacter. Some of these bacteria belong to the normal intestinal flora of animals and man, and many of them seem as a food contamination. Certain members of Citrobacter are suspected to cause enteric infection (Cruickshank et al., 1975)

The entire cluster of family Enterobacteriaceae is of limited use within the examination of food that has probably been concerned in disease outbreak. On the opposite hand, observation of processed for safety, would like family Enterobacteriaceae because the indicator of choice (Mosel et al., 1995)

Concerning the data presented in Table (2), the mean value of coliform count/gm in examined Scomber scombrus , Saurus and Oreochromus niloticus is $1.15 \times 10^{4} \pm 0.17 \times 10^{4}$, $7.92 \times 10^{3} \pm 1.24 \times 10^{3}$ and $3.07 \times 10^{3} \pm 0.51 \times 10^{3}$, respectively. The number of positive samples of Mackerel are 27 with percent of 90 , Saurus are 25 with percent of 83.3 and Oreochromus niloticus are 23 with percent of 76.7

Dealing with results presented in Table (3), it is evident that the mean value of Staph. aureus counts in examined Scomber scombrus, Saurus and Oreochromus niloticus are $4.35 \times 10^{3} \pm 0.62 \times 10^{3}, 1.81 \times 10^{3} \pm 0.29 \times 10^{3}$ and $9.10 \times 10^{2} \pm$ $2.06 \times 10^{2}$, respectively.

Staphylococcus species are major contaminants in fish and fishery products. The presence of Staph. aureus in food is usually associated with improper manipulation by food handlers, who are frequently contaminated with this microorganism (Hatakka et al., 2000). Presence of Staphylococcus in fish indicates its contamination from handlers, inadequate clean instruments, impure water, such contamination represent a public health hazard, this agrees with the statement reported by (Thatcher and Clark, 1975). Staphylococcus food poisoning is caused by ingestion of food containing performed toxins secreted by Staphylococcus aureus and characterized by nausea, vomiting, abdominal pain and prostration usually with symptom while not fever, through 1-6 hours after ingestion of contaminated food (Eley, 1996).

Dealing with results presented in Table (4), it is evident that of histamine levels $\mathrm{mg} \%$ in the examined samples of frozen fish with mean value of $29.40 \pm 0.31,21.76 \pm 0.25$ and $16.23 \pm 0.18$ for Scomber scombrus, Saurus, Oreochromus niloticus, respectively. Results are nearly similar to those obtained by Brink et al., (1990), Rodtong et al., (2005), Gonzaga et al. (2009), Tao et al. (2010), Sigh et al. (2012) and Humaid and Mamdoh (2014), whereas, it was higher than those obtained by Auerswald et al. (2006) and Rajapaksha and Jayakody, (2008), in contrast results were lower than those obtained by Kim et al. (2009). Biogenic amines are biologically active compounds present in variety of food e.g. fish the presence of biogenic amines in these foods is an indicator of spoilage (Vaciana-Nogues et al., 1997). The consumption of histamine may result in toxicological effects to consumers like high blood pressure, headache, diarrhea, rash and localized inflammation (Rawles et al., 1996). Poisoning with amine will cause pseudo-allergic reaction, in other words, it can produce symptoms like urticarial, symptom or spasm of bronchi, the content of histamine is thought to be a criterion of the quality of food (Fletcher et al., 1998). Histamine is produced in fish tissue by the action of bacterial enzymes with the optimum temperature of amine production being $25{ }^{\circ} \mathrm{C}$ (Kim et al., 2009).

Fish is implicated in HFP (histamine fish producing) include both scombroid fish (mackerel, tuna and saury) and nonscombroid fish (sardine, anchovies, blue fish), as they contain large amount of free histidine (Lehane and Olley, 2000). The hazardous level of histamine for human health has been suggested as fifty $\mathrm{mg} \%$, although, low levels as five $\mathrm{mg} \%$ are reported in histamine poisoning (Huss et al., 2003). Biogenic amines in fish as precursors of nitrosamines that is carcinogens (Yurchenko and decompose, 2006). The presence of biogenic amines in food, is considered a health problem because of its physiological and toxic effects (Onal, 2007).

Histamine or scombroid poisoning (scombrotoxism)(HFP) is hypersensitivity associated with the consumption of decomposed fish with toxic histamine levels (4500 ppm) (Hungerford, 2010). He additionally cleared the reason for observation Bas in sea foods is twofold: as indices of decomposition and to prevent the potential toxicity on human health. Symptoms of HFP vary from mild urticaria and oral allergic reactions like syndrome to life threating cardiovascular reactions that can be mistaken for sea food allergy (Lionte, 2010).

Temperature is the most important factor contributing to biogenic amines formation (Chong et al., 2011). High levels of Bas may be prevented by application of good hygiene practices and proper temperature throughout handling, delivery and storage (Visciano et al., 2012).

The content of BAs differ according to species for example Scombridae family, like tuna and bonito and Clupeidae family, like sardines characterized by the presence of high levels of free amine in their muscle, additionally according to the season of the year, genetics, environment, food, 
sex, physiological stage, storage period and sampled tissue (Lee et al., 2012).

Biogenic amines may be used as quality index, once 11 . formed by bacterial activity and are resistant to thermal treatment ,thus reflecting the quality of the raw material and hygienic conditions of food processing (Sagratini et al., 2012).

Preventive measures of freezing and cooling directly after death can prevent rapid development of enzyme histidine decarboxylase, because the hazard control is no possible after formation of enzyme (Anon, 2001). Histamine formation in fish doesn't stop at four c or below; it stops at 13 frozen storage only (Rossano et al., 2006). Toxicological levels of biogenic amines is very difficult to determine because it depends on individual characteristics and the 14 presence of other amine, however, a maximum total Bas levels of 750-900 ppm has been proposed (Ladero et al., 2010)

\section{CONCULOSIONS}

The current study proved that high bacterial counts of 16 . Enterobacteriaceae, Coliform and Staph. ảureus is of high vital correlation with histamine level

\section{REFERENCES}

1. Abbas,K.A.; Mohamed , M.; Jamilah, B. and Ebrahimian, M.(2008): A review on correlation between fish freshness and $\mathrm{pH}$ during cold storage, American Journal of Biochemistry and Biotechnology , 4:416-421.

2. Bagge-Ravan, D. Y.; Hjelm, M.; Christiansen, N.J.; Johansen, C. and Gram, L. (2003): The microbial ecology of processing equipment in different fish industries- analysis of the microflora during processing and following cleaning and disinfection . International Journal of food Microbiology. $87,239-250$

3. Cicero, A. ; Cammilleri, G. ; Galluzzo, F.G. ; Calabrese, I. ;Pulvirenti, A. ; Giangrosso ,G. ; Cicero , N. ; Cumbo , V.; Vella ,A. ; Macaluso , A. and Ferrantelli , V. (2020). Histamine in Fish Products Randomly Collected in Southern Italy: A 6-Year Study. J Food Prot., 16: 241 - 248.

4. Egyptian Organization for Standardization (ES), (2006): Methods of analysis and testing for meat. Part 9: determination of total volatile nitrogen (TVN).ES:63i 9/2006.

5. Egyptian Organization for Standardization (ES), (2006): Methods of analysis and testing for meat. Part 10: determination of thiobarbituric acid (TBA). ES: 63-10/2006.

6. Egyption Organization for Standardization and Quality Control (EOS),(2005): Reports related to No. 1-889-2005 for frozen fish. Egyptian Standards, Ministry of Industry, 24 Egypt.

7. Ekici, K. and Alisarli, M. (2008). Histamine formation and microbiological changes in endemic Chalcalburnus tarichj. Pallas 1811 (Inci Kefali) stored at 4oC. Arch Med Vet., 40: $95-98$.

8. Feldman, D.; Ganon, J.; Haffman, R. and Simpson, J. 26 (2003): The solution for data analysis and presentation graphics. $2^{\text {nd }}$ Ed., Abacus Lancripts, Inc., Berkeley, USA.

9. Food and Drug Administration "FDA" (2001): Staphylococcus aureus. Bacteriological analytical manual 27. $.8^{\text {th }}$ Ed. Chapter12. Academic Press, Gaithersburg, UK.

10. Food and Agriculture Organization of the United 28 Nations/World Health Organization (FAO/WHO). (2013).
Public Health Risks of Histamine and other Biogenic Amines from Fish and Fishery Products. Meeting report.

Food and Drug Administration (FDA). (2001). Fish and fisheries products hazards and controls guidance, 3 rd ed. US FDA Center for Food Safety and Applied Nutrition, Maryland.

12. Food and Drug Administration (FDA). (2011). Fish and Fishery Products Hazards and Controls Guidance, 4th ed. Department of Health and Human Services, Food and Drug Administration, Center for Food Safety and Applied Nutrition, Washington DC.

George , R.M (1997): Freezing Systems. In: Quality in , Frozen Food. Edited by Erickson M.C., and Hung, YenCon. Chapman and Hall, USA. P.484.

Huss, H.H .; Ababouch L. and Gram L. (2003): Assessment and management of seafood safety and quality , FAO Fisheries Technical Paper 444, Rome, 230 pp.

15. ISO "International Standards Organization" (1995): Microbiology of food and animal feeding stuffs. ISO 10272: 1995 (E) International Standards Organization, Geneva, Switzerland.

ISO “International Standards Organization" (4833-1: 2013): Microbiology of food chain- Horizontal method for the enumeration of microorganisms. Part I; Colony count at $30^{\circ} \mathrm{C}$ by the pour plate technique. International Standards Organization, Geneva, Switzerland.

17. ISO "International Standards Organization" (4832: 2006): Microbiology of food and animal feeding stuffs. Horizontal method for the enumeration of coliforms: Colony count technique. International Standards Organization, Geneva, Switzerland.

18. ISO "International Standards Organization" (16649: 2001): Microbiology of food and animal feeding stuffs. Horizontal method for the enumeration of glucuronidase- positive Escherichia coli- Part 2; Colony count technique at $44^{\circ} \mathrm{C}$ using 5-bromo-4-chloro-3-indoly-D-glucuronide. International Standards Organization, Geneva, Switzerland.

19. Joshi, P.A. and Bhoir, V.S. (2011). Study of Histamine Forming Bacteria in Commercial fish samples of Kalyan city. Int. J. Cur. Sci. Res., 1(2): $39-42$.

Kok, T.; Worswich, D. and Gowans, E. (1996): Some serological techniques for microbial and viral infections. In Practical Medical Microbiology (Collee, J.; Fraser, A.; Marmion, B. and Simmons, A., eds.), $14^{\text {th }}$ ed., Edinburgh, Churchill Livingstone, UK.

Krieg and Holt, J.G. (1984): Bergey's Manual of systematic Bacteriology. Vol. 1, Baltimore, MD : Williams \& Wilkins Ladero, V.; Calles-Enríquez, M.; Fernández, M. and Alvarez M.A. (2010).Toxicological effects of dietary biogenic amines. Curr. Nutr. Food Sci., 6: 145 - 156.

Lehane, L. and Olley, J. (2000). Histamine fish poisoning revisited. Int. J. Food Microbiol., 58: 1 - 37.

. Leszczynska, J.; Wiedlocha, M. and Pytasz, U. (2004): The histamine content in some samples of food products. Czech J. Food Sci., 22: 81-86.

Macfaddin, J. F. (2000): Biochemical tests for identification medical bacteria. Williams and Wilkins Press, INC. Baltimore, Md. 21202 USA.

Pearson, D. (2006): Chemical Analysis of Foods. 11 th Ed, Publishing Co., Churchill Livingstone, Edinburgh, London, United Kingdom.

Onal, A.; Tekkeli, S.E.K. and Onal, C. (2013). A review of the liquid chromatographic methods for the determination biogenic amines in foods. Food Chem., 138: 509 -515.

Rahimi, E.F.; Nayebpour, and Alian, F. (2012). Determination of histamine in canned tuna fish using ELISA method. Am. Eurasian. J. Toxicol. Sci., 4: 64 - 66. 
29. Sabry, M.A.; Hayam, A.A.M.; Ashour, R.M. and Hamza, E. (2019). Histamine- Producing Bacteria and Histamine Induction in Retail Sardine and Mackerel from Fish Markets in Egypt. Food borne Pathog. Dis., 16: 597 - 603.

30. Soliman, W.S; Shaapan, R.M.; Mohamed, L.A.; Younes, A. M.; Elgendy, M.Y. and Salah El din, D. A. (2017).
Laboratory Screening of Biogenic Amines Producing Bacteria Potentially Threatens Human Health in Some Egyptian Fish and Fish. Journal of Fisheries and Aquatic Science, 12 (3) 134-140 